\title{
EFFECTS OF EPINEPHRINE ADMINISTRATION ON EPITHELIAL ULTRASTRUCTURE OF TERMINAL BRONCHIOLES IN RABBITS
}

\author{
J. UHLÍK ${ }^{1}$, V. KONRÁDOVÁ ${ }^{1}$, L. VAJNER ${ }^{1}$, J. ZOCOVÁ ${ }^{2}$ \\ ${ }^{1}$ Institute of Histology and Embryology, $2^{\text {nd }}$ Medical Faculty, Charles University, Prague \\ ${ }^{2}$ Department of Applied Mathematics and Computer Science, Faculty of Science, Charles University, Prague \\ Received June 30, 2000 \\ Accepted November 22, 2000 \\ Abstract \\ J. Uhlík, V. Konrádová, L. Vajner, J. Zocová: Effects of Epinephrine Administration \\ on Epithelial Ultrastructure of Terminal Bronchioles In Rabbits. Acta Vet. Brno 2000, 69: 261- \\ 266 \\ In the experiment, the effect of intravenous administration of epinephrine on the ultrastructure of \\ the epithelium of rabbits' terminal bronchioles was studied. Laboratory rabbits were injected with \\ $10 \mu \mathrm{g}$ of epinephrine per $\mathrm{kg}$ of body weight and the material for the electron microscopic \\ examination was collected 5 and 20 minutes post exposure. In both experimental groups, the cells \\ of the epithelium of terminal bronchioles revealed signs of pathological alteration. The effect of \\ epinephrine was concentrated to the secretory Clara cells, in which morphological signs of the \\ liberation of their secretion were often recorded. Nevertheless, statistically significant quantitative \\ changes in the total proportion of epithelial cells or functional state of Clara cells were not \\ ascertained.
}

Airways, ciliated cells, Clara cells, adrenergic stimulation, electron microscopy

During the recent years, many authors have studied the mechanisms controlling the function of secretory cells in airways. Their interest has been concentrated mostly on the mucus-producing goblet cells and on the secretory cells situated in the submucosal glands that produce the major part of airway secretion. In the vicinity of the submucosal glands, nerve endings containing various neurotransmitters were observed on the level of the light and electron microscopy (Laitinen et al. 1985; Rogers and Dewar 1990; Ricci et al. 1997).

The positive effect of the cholinergic stimulation caused by electric irritation of the vagus nerves or administration of acetylcholine or its agonists on the mucus secretion was repeatedly described in various animal species. The tracheal goblet cells and submucosal glands of ferrets and guinea pigs were intensively stimulated to release their secretion (Borson et al. 1984; Tokuy ama et al. 1990; Fung et al. 1992). In our previous studies, the stimulating effect of cholinergic stimulation on the secretory function of the tracheal goblet cells was demonstrated in rabbits (Konrádová et al. 1996a,b).

The effect of the adrenergic stimulation on the secretion of goblet cells and submucosal glands was also studied. The difference between the stimulation of $\alpha$ and $\beta$ adrenergic receptors was demonstrated. The $\alpha$ adrenergic agonists stimulated mostly production of the less viscous, liquid secretion of the submucosal glands. The $\beta$ adrenergic agonists stimulated mostly the mucus-producing cells (B ors on et al. 1984; Gashi et al. 1986; Toku yama et al. 1990). The inhalation of salbutamol, the bronchospasmolytic $\beta_{2}$ adrenergic drug, stimulated and consecutively damaged the tracheal goblet cells in rabbits (SpahrSchopfer et al. 1994; Shorten et al. 1995; Konrádová et al. 1997). Similar, but less pronounced reaction of goblet cells was observed after the inhalation of other $\beta_{2}$ adrenergic bronchospasmolytic substance - fenoterol hydrobromide (Konrádová et al. 1998).

Address for correspondence:

MUDr. Jiří Uhlík

Charles University, $2^{\text {nd }}$ Medical Faculty

V Úvalu 84, CZ-150 06 Praha 5, Czech Republic

Phone: +420224435982

Ex.t. 
The last mechanism influencing the goblet cells and submucosal glands secretion is the so-called non-adrenergic non-cholinergic (NANC) system, in which various peptides (substance $\mathrm{P}$, vasoactive intestinal peptide - VIP), purine nucleotides or nitrogen monoxide (NO) serve as neurotransmitters. This system modifies the function of airway secretory elements by the way of both the autonomic (parasympathetic and sympathetic) nervous system and sensitive nerve endings (Gashi et al. 1986; Ramnarine and Rogers 1994).

Less studies dealing with the neurohumoral regulation of the secretory elements in the small intrapulmonary respiratory passages, where the submucosal glands are absent and the goblet cells are replaced by Clara cells, have been published. In our latter study, we described statistically significant changes in the secretory activity of Clara cells accompanied with the development of signs of pathological alteration of their cytoplasm after the administration of acetylcholine (Uhlík et al. 1999). To extend this study, we decided to perform the experimental evaluation of the ultrastructure of the epithelium of terminal bronchioles in rabbits after the intravenous administration of epinephrine.

\section{Materials and Methods}

Nine specified pathogen free (SPF) rabbits (New Zealand White, males, body weight 1,740 g - 3,080 g) were used. Three untreated rabbits served as controls. Remaining animals received intravenously epinephrine hydrochloride (Adrenalin Léčiva inj., Léčiva, Prague, Czech Republic) at a dose of $10 \mu \mathrm{g} / \mathrm{kg}$ of body weight. The dose was identical to the recommended dose used during the treatment of acute cardiovascular or respiratory failures in humans. The administration of epinephrine and collection of material was done under the general anaesthesia achieved 20 - 30 minutes after the i.m. administration of the mixture of ketamine (Narkamon 5\% inj., Léčiva, Prague, Czech Republic, 35 mg/kg b.w.) and xylazine (Rometar $2 \%$ inj. ad usum vet., Spofa, Prague, Czech Republic). Ten min before the preparation, the cervical region of the animals was infiltrated subcutaneously by procaine (Procain $1 \%$ inj., Léčiva, Prague, Czech Republic).

The material was collected from 3 rabbits 5 and 20 minutes after i.v. administration of the drug, respectively. In the animals, the thorax was opened, lungs were removed and immediately perfused by $5 \%$ glutaraldehyde in $0.1 \mathrm{M}$ cacodylate buffer ( $\mathrm{pH}$ 7.2). From one pulmonary lobe, tiny pieces of the tissue were collected, fixed for 90 minutes with the same fixative and then for 60 minutes with $2 \% \mathrm{OsO}_{4}$ in $0.1 \mathrm{M}$ cacodylate buffer (pH 7.4). The material was dehydrated in graded series of alcohol and embedded in a Durcupan-Epon mixture. Terminal bronchioles were localised in semithin sections stained with toluidine blue. Ultrathin sections were prepared on Ultrotome Nova (LKB, Broma, Sweden), contrasted with uranyl acetate and lead citrate and examined in JEM $100 \mathrm{C}$ electron microscope (Jeol, Tokyo, Japan).

For the quantitative evaluation, the total number of ciliated and Clara cells and the functional state of Clara cells were recorded in the electron microscope using the methods described in our previous paper (Uhlík 1996). The absolute values were given in Table 1 . To compare the results in all experimental groups, the $\chi^{2}$-test of homogeneity in frequency tables was used. To specify categories causing deflections from the hypothesis of homogeneity, adjusted standardised deviations were employed.

\section{Results}

The ultrastructure of the epithelium of terminal bronchioles in control rabbits Terminal bronchioles of healthy control rabbits were lined by a simple epithelium where

Table 1

Quantitative evaluation of the epithelium of terminal bronchioles in rabbits 5 and 20 minutes after i.v. administration of $10 \mu \mathrm{g} / \mathrm{kg}$ of epinephrine (absolute values)

\begin{tabular}{|l|c|c|c|c|c|c|c|c|c|}
\hline & \multicolumn{3}{|c|}{ Controls } & \multicolumn{3}{c|}{$\begin{array}{c}\text { Epinephrine } \\
10 \mu \mathrm{g} / \mathrm{kg} 5 \text { minutes }\end{array}$} & \multicolumn{3}{c|}{$\begin{array}{c}\text { Epinephrine } \\
10 \mu \mathrm{g} / \mathrm{kg} 20 \text { minutes }\end{array}$} \\
\hline Rabbit & 1 & 2 & 3 & 4 & 5 & 6 & 7 & 8 & 9 \\
\hline Total number of cells & 250 & 173 & 178 & 302 & 131 & 264 & 211 & 274 & 182 \\
\hline Ciliated cells & 127 & 77 & 80 & 132 & 59 & 127 & 85 & 122 & 76 \\
\hline Clara cells & 123 & 96 & 98 & 170 & 72 & 137 & 126 & 152 & 106 \\
\hline CC with granules & 79 & 73 & 81 & 125 & 55 & 104 & 87 & 105 & 87 \\
\hline CC without granules & 44 & 23 & 17 & 45 & 17 & 33 & 39 & 47 & 19 \\
\hline
\end{tabular}

$\mathrm{CC}=$ Clara cells 
low columnar or cuboidal ciliated cells and high columnar Clara cells alternated almost regularly. In our previous paper, the arrangement and the ultrastructure of both types of the epithelial cells were described in detail (Uhlík 1996).

In the epithelium of the terminal bronchioles of healthy control rabbits, the Clara cells and the ciliated ones represented $52.7 \pm 3.6 \%$ and $47.3 \pm 3.6 \%$ of epithelial cells, respectively (Fig. 1). In the majority of Clara cells ( $73.5 \pm 9.4 \%$ ), secretory granules were discovered (Fig. 2).

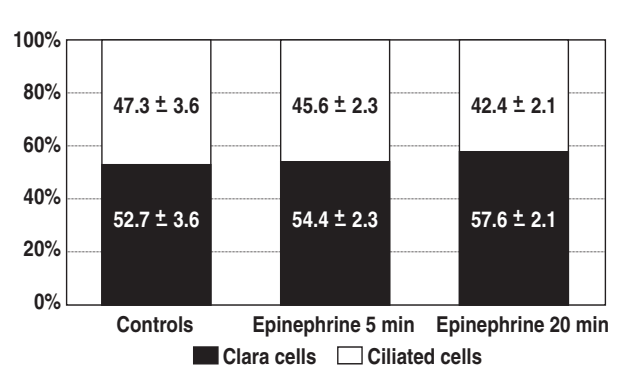

Fig. 1. Quantitative evaluation of the epithelium of terminal bronchioles in rabbits 5 and 20 minutes after i.v. administration of $10 \mu \mathrm{g} / \mathrm{kg}$ of epinephrine.

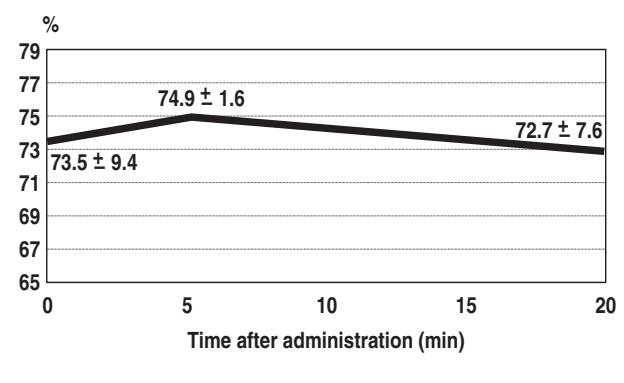

Fig. 2. Clara cells containing secretory granules in the epithelium of terminal bronchioles 5 and 20 minutes after i.v. administration of $10 \mu \mathrm{g} / \mathrm{kg}$ of epinephrine.

The ultrastructure of the epithelium of terminal bronchioles in rabbits 5 minutes after administration of $10 \mu \mathrm{g} / \mathrm{kg}$ of epinephrine

Five minutes post exposure, the terminal bronchioles of experimental animals were lined with a simple epithelium composed of ciliated and Clara cells. Apical junctional complexes were intact, intercellular spaces remained narrow (Plate I, Fig. 3).

Cortical regions of the ciliated cells were intact. Kinocilia observed on the apical surfaces were mostly of the typical ultrastructure; only small number of altered cilia with slightly increased amount of cytoplasm between the axoneme and the ciliary membrane was recorded. Tiny apical cytoplasmic protrusions containing occasionally the axoneme of 1 or 2 cilia were found only exceptionally. In deeper portions of the ciliated cells' cytoplasm, slightly dilated spaces of the Golgi complex and cisternae of the rough endoplasmic reticulum were observed. More frequently than in control animals, small vacuoles and tiny lysosomes with a heterogeneous content were recorded (Plate I, Fig. 4). Extensive focal cytoplasmic degradations were occasionally found, too. In some ciliated cells, mitochondria revealed signs of pathological alteration (Fig. 4).

The cytoplasm of Clara cells contained slightly dilated tubules of the smooth endoplasmic reticulum (Plate I, Fig. 5); cisternae of the rough endoplasmic reticulum and Golgi complex were more voluminous than in control animals. Mitochondria revealed similar signs of the pathological alteration as in the ciliated cells (Fig. 5). The number of secretory granules situated in the cytoplasm of the Clara cells was extremely small. Signs of the liberation of secretion were often ascertained - electron dense, oval or spherical granules were situated in the contact with the apical plasma membrane or were incorporated in apical cytoplasmic protrusions. In these protrusions, also remnants of evacuated secretory granules were observed. As a sign of the apocrine secretion, free secretory granules enveloped by a thin layer of cytoplasm were found above the epithelium.

Five minutes after i.v. administration of $10 \mu \mathrm{g} / \mathrm{kg}$ of epinephrine, $45.6 \pm 2.3 \%$ of ciliated cells and $54.4 \pm 2.3 \%$ of Clara cells were encountered in the epithelium of terminal bronchioles (Fig. 1). $74.9 \pm 1.6 \%$ of Clara cells contained secretory granules in their cytoplasm (Fig. 2). 
The ultrastructure of the epithelium of terminal bronchioles in rabbits 20 minutes after administration of $10 \mu \mathrm{g} / \mathrm{kg}$ of epinephrine

Twenty minutes post exposure, the terminal bronchioles were lined with an altered simple epithelium composed of ciliated and Clara cells. Apical junctional complexes and intercellular spaces were not altered.

On the ciliated cells, the process of apical blebbing was more pronounced than 5 minutes post exposure. Isolated axonemes of kinocilia situated in the apical cytoplasmic protrusions gradually degenerated and disintegrated (Plate I, Fig. 6). Compared with the previous group, altered pathological kinocilia were found on the apical surfaces of the ciliated cells more frequently. In the deeper area of the cytoplasm, similar signs of the pathological alteration as in the previous experimental group were observed.

In the cytoplasm of the Clara cells, tubules of the smooth endoplasmic reticulum and cisternae of the Golgi complex and rough endoplasmic reticulum were more dilated than in the previous group (Plate II, Fig. 7). Contrariwise, the degree of swelling of mitochondria was less pronounced (Fig. 7). Numerous morphological signs of liberation of the secretory granules' content were still observed. The secretory granules were tightly attached to the apical plasma membrane or situated in the apical cytoplasmic protrusions of Clara cells (Plate II, Fig. 8). Remnants of the altered cytoplasm of Clara cells containing secretory granules, widely dilated tubules of smooth endoplasmic reticulum and altered mitochondria were occasionally found above the epithelium in the lumen of the terminal bronchioles (Plate II, Fig. 9).

Twenty minutes after the i.v. administration of $10 \mu \mathrm{g} / \mathrm{kg}$ of epinephrine, slightly increased occurrence of differentiating epithelial cells was recorded. Mostly differentiating ciliated cells in various stages of the ciliogenesis were observed (Plate II, Fig. 10).

Twenty minutes post exposure, the epithelium of terminal bronchioles was composed of $42.4 \pm 2.1 \%$ of ciliated cells and $57.6 \pm 2.1 \%$ of Clara cells (Fig. 1). Secretory granules were found in $72.7 \pm 7.6 \%$ of Clara cells (Fig. 2).

\section{Discussion}

The intravenous administration of epinephrine in the dose of $10 \mu \mathrm{g} / \mathrm{kg}$ of body weight evoked in the epithelium of rabbits' terminal bronchioles the reaction that is similar to that after the administration of various toxicants. The signs of the pathological alteration of the Clara cells were identical to those observed after the parenteral administration of polycyclic aromatic compounds (naphthalene, 4-ipomeanol) (Plopper et al. 1992ab;1994a; Van Winkle et al. 1995; Lakritz et al. 1996), inhalation of trichloroethylene (Giovanetti et al. 1998) or after inhalation of ozone (Harkema et al. 1993; Plopper et al. 1994b). Very similar findings were described in the epithelium of terminal bronchioles after the administration of the iodinated contrast agent iopamidol used for tracheobronchography (Uhlík and Tůma 1998).

The mild pathological alteration of the ciliated cells was comparable to the findings in the ciliated cells of the terminal bronchioles observed after the intravenous administration of acetylcholine (Uhlík et al. 1999) or after the above-mentioned contact with the iodinated contrast agent. Similar changes were described in the tracheal ciliated cells 5 and 20 minutes after the i.v. administration of epinephrine in the same dose as in the present study (Konrádová et al. 1999).

In our previous study, the effect of intravenous administration of acetylcholine in two different doses $(0.1$ and $0.5 \mathrm{mg})$ on the ultrastructure of the epithelium of terminal bronchioles in rabbits was studied. Five minutes post exposure, the statistically significant suppression of the secretory activity of Clara cells accompanied with the occurrence of 
moderate signs of the pathological alteration of their cytoplasm was recorded. Five minutes after the administration of the higher dose of acetylcholine, some altered Clara cells degenerated and were sloughed off the epithelium. Twenty minutes after the administration of $0.5 \mathrm{mg}$ of acetylcholine, mild but statistically significant marks of stimulation of the Clara cells' secretory function were ascertained (Uhlík et al. 1999). Similar statistically significant changes of the Clara cells' secretory activity were not observed after the administration of epinephrine. The increased occurrence of the morphological signs of the liberation of their secretion did not reflect the quantitative evaluation of the functional state of these cells.

In the tracheal epithelium, the reaction of secretory elements to the administration of $10 \mu \mathrm{g} / \mathrm{kg}$ of epinephrine was pronounced. The goblet cells were highly stimulated to release their secretion. Twenty minutes post exposure, $70 \%$ of them were completely exhausted. These cells did not take part in the further secretory cycles, but degenerated and were gradually expelled from the epithelium (Konrádová et al. 1999). The mild reaction of the Clara cells due to the administration of the same dose of epinephrine sharply contrasted with the conspicuous reaction of the tracheal goblet ones.

Van Scott with his fellow-workers described very similar difference between the reaction of the Clara cells and tracheal epithelial cells in vitro to the administration of $\beta$-adrenergic drug isoproterenol (V an Scott et al. 1995). These findings lead to the conclusion that the reaction of secretory cells to the neurohumoral stimulation differs in different levels of the airways.

\section{Účinek aplikace adrenalinu na ultrastrukturu epitelu terminálních bronchiolů králíků}

V experimentu jsme studovali vliv intravenózní aplikace adrenalinu na ultrastrukturu epitelu terminálních bronchiolů. Laboratorním králíkům jsme podali $10 \mu \mathrm{g}$ adrenalinu na $\mathrm{kg}$ tělesné hmotnosti a materiál pro elektronově mikroskopické vyšetření jsme odebírali 5 a 20 minut po aplikaci. V obou experimentálních skupinách jevily buňky epitelu terminálních bronchiolů známky patologické alterace. Účinek adrenalinu byl zaměřen více na sekrečnî Clara buňky, v nichž jsme zaznamenali častý výskyt morfologických známek uvolňování sekretu. Ke statisticky významným kvantitativním změnám v zastoupení jednotlivých typů buněk v epitelu a ve funkčním stavu Clara buněk však nedošlo.

\section{Acknowledgement}

This study was supported by the Czech Ministry of Education, Youth and Sports (Research Project No. 111300003)

\section{References}

BORSON, D. B., CHARLIN, M., GOLD, B. D., NADEL, J. A. 1984: Neural regulation of ${ }^{35}$ SO $_{4}$-macromolecule secretion from tracheal glands of ferrets. J. Appl. Physiol.: Respirat. Environ. Exercise Physiol. 57: 457-466

FUNG, D. C. K., BEACOCK, D. J., RICHARDSON, P. S. 1992: Vagal control of mucus glycoconjugate secretion into the feline trachea. J. Physiol. 453: 435-447

GASHI, A. A., BORSON, D. B., FINKBEINER, W. E., NADEL, J. A., BASBAUM, C. B. 1986: Neuropeptides degranulate serous cells of ferret tracheal glands. Am. J. Physiol. 251 (Cell Physiol. 20): C223-C229

GIOVANETTI, A., ROSSI, L., MANCUSO, M., LOMBARDI, C. C., MARASCO, M. R., MANNA, F., ALTAVISTA, P., MASSA, E. M. 1998: Analysis of lung damage induced by trichloroethylene inhalation in mice fed diets with low, normal, and high copper content. Toxicol. Pathol. 26: 628-635

HARKEMA, J. R., PLOPPER, C. G., HYDE, D. M., ST GEORGE, J. A., WILSON, D. W., DUNGWORTH, D. L. 1993: Response of macaque bronchiolar epithelium to ambient concentrations of ozone. Am. J. Pathol. 143: 857-866

KONRÁDOVÁ, V., UHLÍK, J., VAJNER, L., ZAJÍCOVÁ, A., ZOCOVÁ, J. 1996a: Ultrastructure of the tracheal epithelium in rabbits after acetylcholine administration. Folia Biol. 42: 261-265

KONRÁDOVÁ, V., UHLÍK, J., VAJNER, L., ZOCOVÁ, J. 1996b: Reaction of the goblet cells to the cholinergic stimulation. Acta Vet. Brno 65: 175-180

KONRÁDOVÁ, V., UHLÍK, J., VAJNER, L., ZOCOVÁ, J. 1997: Effect of an adrenergic agonist and a cholinergic antagonist on the airway epithelium. Vet. Med. - Czech 42: 289-293 
KONRÁDOVÁ, V., UHLÍK, J., VAJNER, L., ZOCOVÁ, J. 1998: The effect of two $\beta_{2}$ adrenergic agonists on the ultrastructure of the airway epithelium in rabbits. Vet. Med.- Czech. 43: 187-192

KONRÁDOVÁ, V., UHLÍK, J., VAJNER, L., ZOCOVÁ, J. 1999: The effect of adrenergic stimulation on the ultrastructure of the tracheal epithelium. Biologia Bratislava 54, Suppl.6: 169-175

LAITINEN, A. 1985: Autonomic innervation of the human respiratory tract as revealed by histochemical and ultrastructural methods. Eur. J. Resp. Dis. 66, Suppl. 140: 5-42

LAKRITZ, J., CHANG, A., WEIR, A., NISHIO, S., HYDE, D., PHILPOT, R., BUCKPITT, A. R., PLOPPER, C. G. 1996: Cellular and metabolic basis of Clara cell tolerance to multiple doses of cytochrome P450-activated cytotoxicants. I: Bronchiolar epithelial reorganization and expression of cytochrome P450 monoxygenases in mice exposed to multiple doses of naphthalene. J. Pharmacol. Exp. Ther. 278: 1408-1418

PLOPPER, C. G., MACKLIN, J., NISHIO, S. J., HYDE, D. M., BUCKPITT, A. R. 1992a: Relationship of cytochrome P-450 activity to Clara cells cytotoxicity. III. Morphometric comparison of changes in the epithelial populations of terminal bronchioles and lobar bronchi in mice, hamsters, and rats after parenteral administration of naphthalene. Lab. Invest. 67: 553-565

PLOPPER, C. G., SUVERKROPP, C., MORIN, D., NISHIO, S., BUCKPITT, A. 1992b: Relationship of cytochrome P450 activity to Clara cell cytotoxicity. I. Histopathologic comparison of the respiratory tract of mice, rats and hamsters after parenteral administration of naphthalene. J. Pharmacol. Exp. Ther. 261: 353-363

PLOPPER, C. G., WEIR, A. J., NISHIO, S. J., CHANG, A., VOIT, M., PHILPOT, R. M., BUCKPITT, A. R. 1994a: Elevated susceptibility to 4-ipomeanol cytotoxicity in immature Clara cells of neonatal rabbits. J. Pharmacol. Exp. Ther. 269: 867-880

PLOPPER, C. G., CHU, F., HASELTON, C. J., PEAKE, J., WU, J., PINKERTON, K. E. 1994b: Dose-dependent tolerance to ozone. I. Tracheobronchial epithelial reorganization in rats after 20 months' exposure. Am. J. Pathol. 144: 404-420

RAMNARINE, S. I., ROGERS, D. F. 1994: Non-adrenergic, non-cholinergic neural control of mucus secretion in airways. Pulmonary Pharmacology 7: 19-33

RICCI, A., MARIOTTA, A., GRECO, S., PALLONE, G., PAPALE, M., BISETTI, A. 1997: Age-related changes of the noradrenergic innervation of rat tracheo-bronchial tree and pulmonary vasculature. Mechanisms of Ageing and Development 99: 245-255

ROGERS, D. F., DEWAR, A. 1990: Neural control of airway mucus secretion. Biomed. \& Pharmacother. 44: 447453

SHORTEN, G. D., DOLOVICH, M., ENG, P., LERMAN, J., CUTZ, E. 1995: Metered -dose inhaler salbutamolinduced tracheal epithelial lesions in intubated rabbits. Chest 108: 1668-1672

SPAHR-SCHOPFER, I. A., LERMAN, J., CUTZ, E., NEWHOUSE, M. T., DOLOVICH, M. 1994: Proximate delivery of a large experimental dose from salbutamol MDI induces epithelial airway lesions in intubated rabbits. Am. J. Respir. Crit. Care Med. 150: 790-794

TOKUYAMA, K., KUO, H., ROHDE, J. A. L., BARNES, D. J., ROGERS, D. F. 1990: Neural control of goblet cell secretion in guinea pig airways. Am. J. Physiol. 259: L108-L115

UHLÍK, J. 1996: Quantitative evaluation of findings in the epithelium of terminal bronchioles in healthy rabbits. (Oryctolagus cuniculus var. edulis). Acta Vet. Brno 65: 181-184

UHLÍK, J., TŮMA, S. 1998: Effect of intratracheal administration of iopamidol on the ultrastructure of the epithelium of terminal bronchioles in rabbits (Oryctolagus cuniculus var. edulis). Acta Vet. Brno 67: 97-101

UHLÍK, J., KONRÁDOVÁ, V., VAJNER, L., ZOCOVÂ, J. 1999: Ultrastructure of the epithelium of terminal bronchioles in rabbits after the administration of acetylcholine. Acta Vet. Brno 68: 179-184

VAN SCOTT, M. R., PENLAND, C. M., WELCH, C. A., LAZAROWSKI, E. 1995: $\beta$-adrenergic regulation of $\mathrm{Cl}^{-}$and $\mathrm{HCO}_{3}^{-}$secretion by Clara cells. Am. J. Respir. Cell Mol. Biol. 13: 344-351

VAN WINKLE, L. S., BUCKPITT, A. R., NISHIO, S. J., ISAAC, J. M., PLOPPER, C. G. 1995: Cellular response in naphthalene-induced Clara cell injury and bronchiolar epithelial repair in mice. Am. J. Physiol. 269: L800L818 
Plate I

Uhlík J. et al.: Effects of ... pp. 261-266
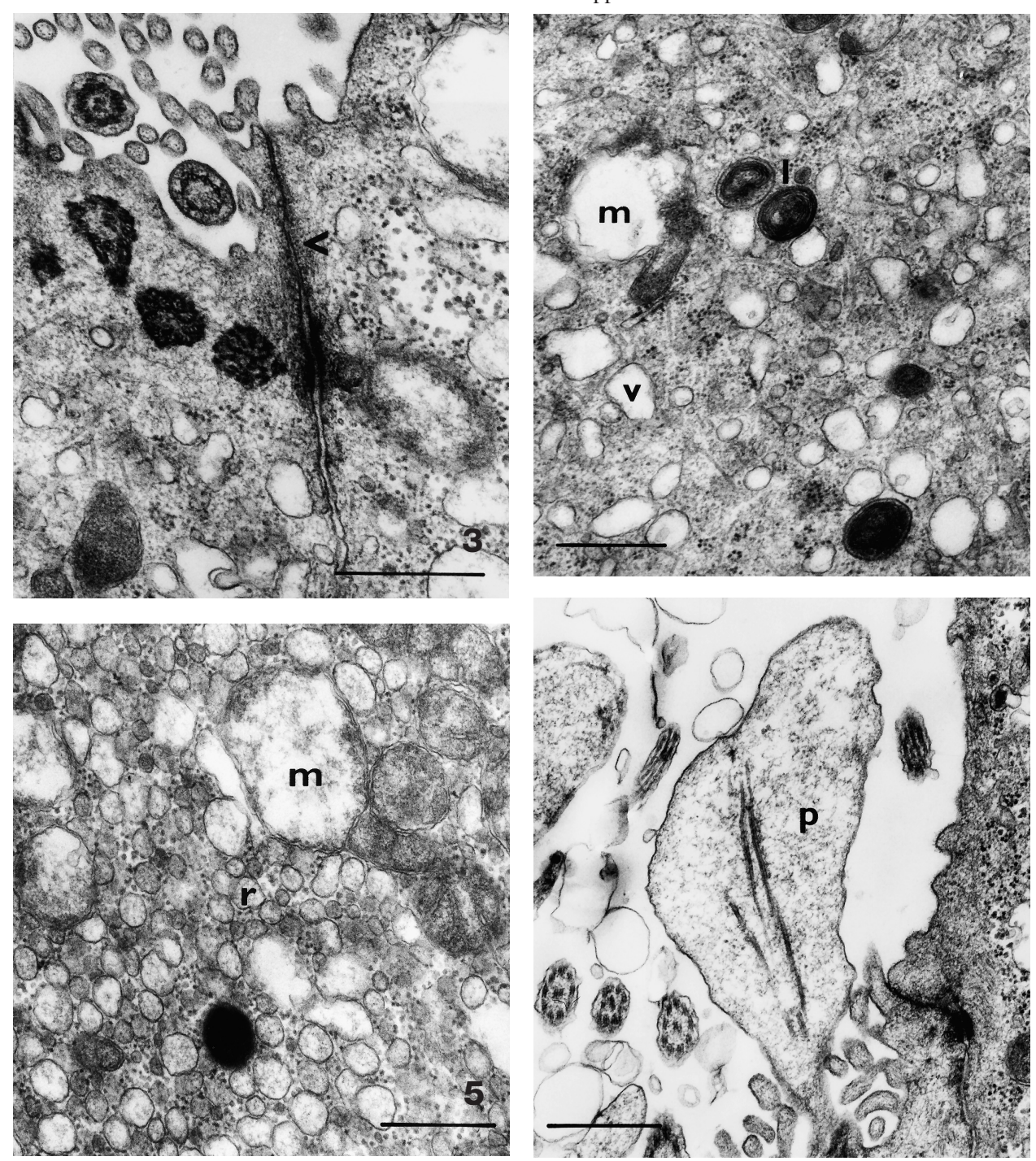

Fig. 3. An intact apical junctional complex (arrowhead) between a ciliated cell and a Clara cell. 5 minutes after i.v. administration of $10 \mu \mathrm{g} / \mathrm{kg}$ of epinephrine $-\times 50,000$.

Fig. 4: Tiny vacuoles (v), secondary lysosomes (1) and altered mitochondria ( $\mathrm{m}$ ) in the cytoplasm of a ciliated cell. 5 minutes after i.v. administration of $10 \mu \mathrm{g} / \mathrm{kg}$ of epinephrine $-\times 37,500$.

Fig. 5: Slightly dilated tubules of the smooth endoplasmic reticulum (r) and altered mitochondria (m) in the cytoplasm of a Clara cell. 5 minutes after i.v. administration of $10 \mu \mathrm{g} / \mathrm{kg}$ of epinephrine $-\times 37,500$.

Fig. 6: An apical cytoplasmic protrusion (p) containing an axoneme of a disintegrating cilium on the surface of a ciliated cell. 20 minutes after i.v. administration of $10 \mu \mathrm{g} / \mathrm{kg}$ of epinephrine $-\times 37,500$. 
Plate II
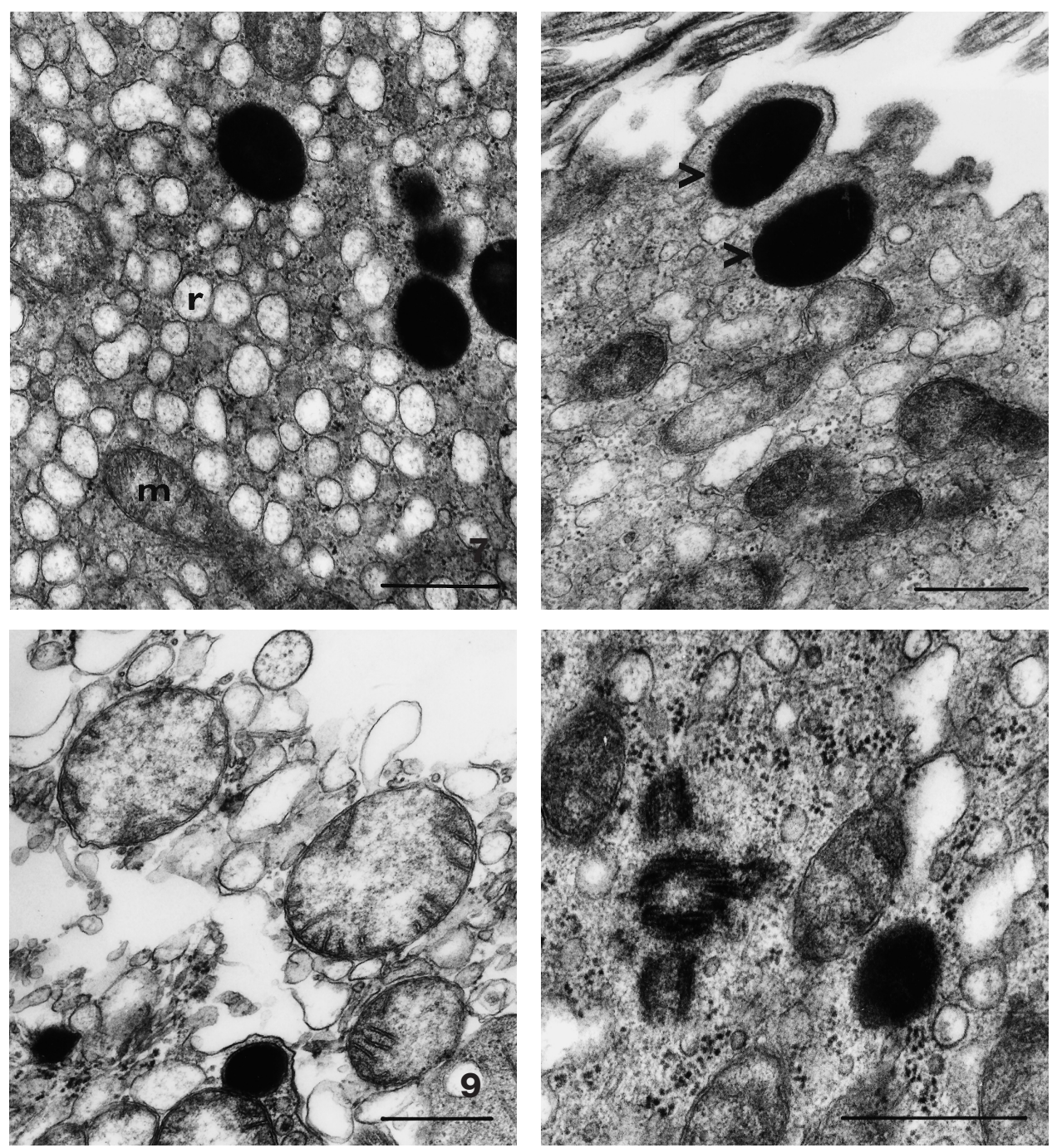

Fig. 7. Moderately dilated tubules of the smooth endoplasmic reticulum (r) and almost intact mitochondria $(\mathrm{m})$ in the cytoplasm of a Clara cell. 20 minutes after i.v. administration of $10 \mu \mathrm{g} / \mathrm{kg}$ of epinephrine $-\times 37,500$.

Fig. 8. Secretory granules (arrowheads) situated in a close vicinity to the apical plasma membrane or even in a small apical cytoplasmic protrusion of a Clara cell. 20 minutes after i.v. administration of $10 \mu \mathrm{g} / \mathrm{kg}$ of epinephrine $\times 37,500$.

Fig. 9. Remnants of an altered cytoplasm of a Clara cell situated above the epithelium in the lumen of a terminal bronchiole. 20 minutes after i.v. administration of $10 \mu \mathrm{g} / \mathrm{kg}$ of epinephrine $-\times 37,500$.

Fig. 10. A portion of the cytoplasm of a differentiating ciliated cell. 20 minutes after i.v. administration of $10 \mu \mathrm{g} / \mathrm{kg}$ of epinephrine $-\times 62,500$.Bars are equal to $0.5 \mu \mathrm{m}$. 